\title{
Vibrational olfaction in flies and humans
}

\author{
Luca Turin
}

From 1st International Workshop on Odor Spaces

Hannover, Germany. 4-7 September 2013

Abstract available at [1].

Published: 16 April 2014

\section{Reference}

1. [http://www.nist.gov/public_affairs/colloquia/20110107.cfm].

Submit your next manuscript to BioMed Central and take full advantage of:

- Convenient online submission

- Thorough peer review

- No space constraints or color figure charges

- Immediate publication on acceptance

- Inclusion in PubMed, CAS, Scopus and Google Scholar

- Research which is freely available for redistribution

( 2014 Turin; licensee BioMed Central Ltd. This is an Open Access article distributed under the terms of the Creative Commons 